\title{
STUDY OF THE EFFECT OF VALSARTAN ON ADJUVANT-INDUCED ARTHRITIS IN ALBINO RATS
}

\author{
By \\ Somaia A. Mokbel,
}

\author{
From \\ department of clinical pharmacolog Mansoura \\ Faculty of medicine, Egypt.
}

\begin{abstract}
The present work was conducted to investigate the influence of valsar$\tan$ (a highly selective antagonist on angiotensin II type-1 receptors (AT 1 $R$ blocker) in rats with experimentally - induced inflammation in the form of collagen II- induced adjuvant arthritis.
\end{abstract}

Thirty two, healthy male albino rats were used throughout this study. Rats were divided into 4 equal groups, each comprised 8 rats. The first group consisted of non-arthritic animals (normal control). This group received intra-gastrically normal saline (the vehicle used to dissolve drugs), for 2 weeks. The second group consisted of arthritic rats that received intragastrically saline for 2 weeks \& served as an arthritic control. The third group consisted of arthritic rats treated with indomethacin (nonsteroidal anti-inflammatory drug, NSAID) in a daily dose of $1.3 \mathrm{mg} / \mathrm{kg}$ for the same previously mentioned duration \& by the same route of adminiistration. The fourth group consisted of arthritic rats treated with a daily intra-gastric dose of valsartan $(20 \mathrm{mg} / \mathrm{kg}$ ) for 2 weeks.

It was found that administration of collagen II \& complete freund's adjuvant to rats produced a significant arthritic changes as assessed by paw oedema thickness, analgesmetric pressure \& $\mathrm{C}$-reactive protein (CRP). Furthermore arthritic rats showed a significant increase in fibronectin (fn) \& malondialdehyde (MDA) ; an indicator of free oxygen radical. Daily in-

MANSOURA MEDICAL JOURNAL 
tra-gastric administration of either indomethacin or valsartan induced a significant decrease in the paw oedema thickness, CRP, MDA as well as induced increase in analgesmetric pressure tolerance, these results suggested that valsartan has a potential anti-inflammatory effect in collagen II induced adjuvant arthritis (this is in addition to its known antihypertensive effect).

\section{INTRODUCTION}

Angiotensin II (Ang II) has emerged as an important growth factor for vascular, cardiac \& renal cells. Depending on the specific cell type \& presence of other growth factors, Ang II induces hypertrophy (increase cell size, cell protein \& mRNA content without DNA replication), proliferation (replication of DNA with subsequent successful division of cells), apoptosis (programmed cell death) or differentiation. Such Ang II-mediated modulation of growth process may underlie various pathophysiological processes such as atherosclerosis, vascular \& cardiac remodling, and progression of chronic renal disease (1). It is widely accepted that Ang $\|-1$ receptors
$\left(A T_{1} R\right)$ account for the majority of cardiovascular effects evoked by Ang II, such as contraction / pressor activity and growth-promoting effects leading to cardiac and vascular hypertrophy. However,there has been increasing evidence indicating that Ang II type-2 receptors (AT2 R) may exert pharmacological action per se as well as play a role in pathophysiological processes. In addition Angll increases expression \& production of Fn \& collagen type 1, chondroitin / dermatan sulphates \& proteoglycans (2). In particular it has been suggested that AT2 R may exert a beneficial vasodilator \& anti-growth effects, as well as contribute to the efficacy of $A T_{1} R$ antagonists (2).

Rheumatoid arthritis (RA) is a common inflammatory autoimmune disorder with a widely varying degree of severity (3). Non-steroidal antiinflammatory drugs have become an integral part of the rheumatological disorders therapy (4). Patients who are at risk of adverse effects of these drugs are rapidly exposed to well known gastro-intestinal \& renal toxicity (5). 
Valsartan

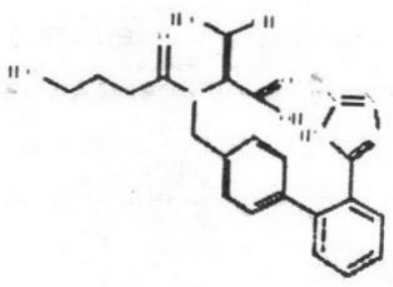

\section{LOSARTAN}

Losartan monopotassium salt

Losartan carboxy acid $\mathrm{HCl}$

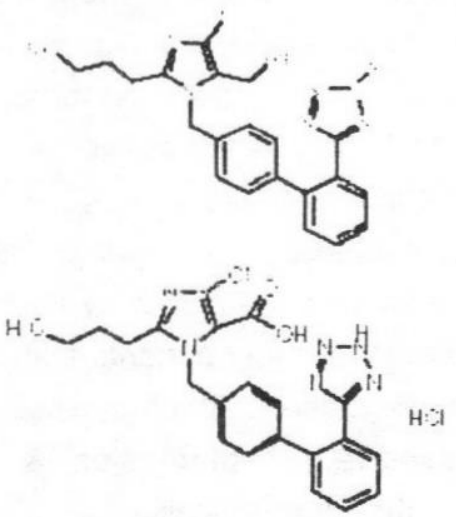

Valsartan is a highly a highly sesuggested that Valsartan had benefilective, orally available antagonist of $A T_{1}$ receptors. Valsartan is a nonheterocyclic antagonist in which the imidazole of losartan has been replaced with an acylated amino-acid (see the above figure). Valsartan doesn't need to be metabclized to be effective, and it is excreted both by the bile $(70 \%)$ \& the kidney $(30 \%)$. There is only one inactive metabolite for Valsartan. Food decreased drug absorption by $40 \%$ like losartan, valsartan lacks affinity for adrenergic, histamine, substance $P$, muscarinic \& serotonin receptors $(6)$. It has been cial effects in patients with hypertensive end-organ damage such as renal disease and left ventricular hypertrophy. Furthermore, the drug is evaluated for its efficacy in heart failure and patients with myocardial infarction (7). Siragy et al., (8) reported that AT1R blockade with Valsartan induced a potential anti-inflammatory effect through prevention of the increase in tumor necrosis factor alpha in diabetic rats. This finding of Valsartan is new in addition to its known antihypertensive effects

MANSOURA MEDICAL JOURNAL 
Stoboda et al., (9) reported that type II collagen -induced adjuvant arthritis in rats is an experimental model of RA that simulating RA in humans.

The aim of the present work is to study the effect of valsartan in collagen II - induced adjuvant arthritis in rats to declare the above finding in diabetic rats \& to study its mechanism. Such possible finding of exerting antiinflammatory action may be of future benefit to many patients suffering RA in association with cardiovascular diseases (e.g. hypertension) \& in need for the use of valsartan to control such problems.

\section{MATERIAL AND METHODS} Drugs used:

- Diovan tab. (Valsartan, $160 \mathrm{mg}$ ), supplied by Novartis Co.

- hodcid tab. (indomethacin, $25 \mathrm{mg}$ ) supplied by Cairo Co.

\section{Animals used:}

Thirty two, healthy, male albino rats aged 3-4 months \& weighing 150 200 grams were used throughout the experiment. They were put under similar housing conditions, kept on diet of milk \& bread. They, liberally supplied with water.

Vol. 36, No. 3 \& 4 July., \& Oct, 2005
Animals grouping:

The experiment included 4 equal animal groups, each consisting of 8 rats. They were divided as the following :

- Group (1) : non-arthritic control rats tr eated with intra-gastric saline for 2. weeks (normal control).

- Group (2) : arthritic rats treated with intra-gastric saline (the vehicle) \& Served as non-treated arthritic control.

- Group (3) : arthritic rats treated with indomethacin in a single daily intra-gastric dose of $1.3 \mathrm{mg} / \mathrm{kg}$ for 2 weeks (10).

- Group (4) : consisted of arthritic rats treated with valsartan in a daily dose of $20 \mathrm{mg} / \mathrm{kg} /$ day by the same previously mentioned route $\&$ for the same duration (11).

Adjuvant induced arthritis was produced in albino rats according to Eckhardt (12). Inflammatory \& antiinflammatory effects (pain tolerance \& oedema development and suppression) were assessed by using analgesymeter (Fig. 4) \& paw oedema tests (Fig. 3) respectively $(13,14)$. CRP was measured by using latex particles agglutination (15). CRP may be the parameter of choice among acute phase proteins that reflects inflamma- 
tion (16). Lipid peroxidation was assessed spectrophotometrically by measuring (MDA) using the thiobarbituric acid method (17). Estimation of (Fn) by single radial immuno-diffusion plates. These plates were obtained from Behring werke, AG, Marburg, w. Germany (18). In addition to assessment of serum creatinine according to seeling \& wust (19).

\section{STATISTICAL ANALYSIS}

Student "t" test according to Pipkins (20), was used to determine the degree of significance between samples. The difference was regarded as significant when $P=$ or $<0.05$.

\section{RESULTS}

Inducation of collagen II - adjuvant arthritis produced a significant decrease in analgesmetric pressure tolerance, significant increase in paw oedema thickness as well as a significant increase in CRP \& Fn. (table 1).

Furthermore, arthritic rats showed increase in free oxygen radical as indicated by MDA (Table 2).

Daily administration of either valsartan $(20 \mathrm{mg} / \mathrm{kg} /$ day) or indomethacin (1.3 mg/kg/day), for 2 weeks produced a significant increase in analgesmetric pressure tolerated by arthritic rats. In addition these rats showed a significant decrease in paw oedema thickness as well as decrease in CRP \& MDA, but without changes in serum creatinine. As regards, $\mathrm{Fn}$, there was no significant changes produced by indomethacin.. In contrast administration of valsartan to arthritic rats produced significant decrease in $\mathrm{Fn}$. These findings are in comparison to arthritic non-treated control rats; table $\left(\begin{array}{l}1 \\ 1\end{array} 2\right)$ \& Fig. $(1,2,5,6 \& 7)$. 
Table (1): Inflammatory reaction as assessed by analgesmetry, paw oedema thickness, CRP \& fn.levels in arthritic \& non-arthritic rats (MeantSE):

\begin{tabular}{|c|c|c|c|c|c|c|}
\hline \multirow{2}{*}{ Grontp, $n=s$} & \multicolumn{2}{|c|}{$\begin{array}{l}\text { Analyesmetric } \\
\text { pressure (grams) }\end{array}$} & \multicolumn{2}{|c|}{$\begin{array}{l}\text { Paw vedema } \\
\text { thickness }(\mathrm{mm})\end{array}$} & \multirow{2}{*}{$\begin{array}{l}\text { Fibronectin } \\
\text { in, }(\mathrm{mg} / \mathrm{L})\end{array}$} & \multirow{2}{*}{$\begin{array}{l}\text { c-reactive } \\
\text { protein CRP, } \\
(\mathrm{mg} / \mathrm{L})\end{array}$} \\
\hline & $\begin{array}{l}\text { Right } \\
\text { paw (R) }\end{array}$ & $\begin{array}{l}\text { Lett } \\
\text { paw (L) }\end{array}$ & $\begin{array}{l}\text { Right } \\
\text { paw (R) }\end{array}$ & $\begin{array}{l}\text { Left } \\
\text { paw (L) }\end{array}$ & & \\
\hline $\begin{array}{l}\text { Non-arthritic } \\
\text { control rats }\end{array}$ & $210 \pm 8.1$ & $201 \pm 3.3$ & $23 \pm 0.12$ & $2+.6 \pm 0.22$ & $21.8 \pm 1.88$ & $\begin{array}{l}<6 . \mathrm{ng} / \mathrm{L} \\
\text { no agglutination }\end{array}$ \\
\hline $\begin{array}{l}\text { Arthritic } \\
\text { control rats }\end{array}$ & $130 \pm 10.5$ & $115 \pm 1.3$ & $40.2 \pm 0.19$ & $4(0.8 \pm(1) .19$ & $36 . + \pm 1.04$ & $85.5 \pm 6.09$ \\
\hline $\mathrm{F}$ & $\because 0.001$ & $<0.001$ & $<0 .(00) 1$ & <ii.voli & $<0.0001$ & $<0 .(x) 1$ \\
\hline
\end{tabular}

$\mathrm{SE}=$ Standard error.

$P=$ Test of significance between the test group (arthritic rats) \& non-arthritic control.

Table (2): Serum Malondialdehyde (bI) $\$$ ) \& serunt crcatinine in arturitic \& non-arthritic control rats (mean $\pm S E$ ):

\begin{tabular}{|c|c|c|}
\hline Group $n=8$ & $\begin{array}{l}\text { Malondialuehyde } \\
\text { (MDA) (nmoL/L) }\end{array}$ & $\begin{array}{c}\cdot i \text { : } \\
\text { Scrum creatinine }(m g / d L)\end{array}$ \\
\hline Non-arthritic corisni rat & $0.12 \pm 0.00$ & $0.98 \pm 0.02$ \\
\hline Arthritic control rats & $0.408 \pm 0.02$ & $0.99 \pm 0.03$ \\
\hline$P$ & $P<0.001$ & $P>0.05(N S)$ \\
\hline
\end{tabular}

Sl:=- Standard error.

NS $=$ non significant

$p=$ Test of signiticance between non-arthritic \& arthritic control group

Vol. 36, No. 3 \& 4 July., \& Oct, 2005 


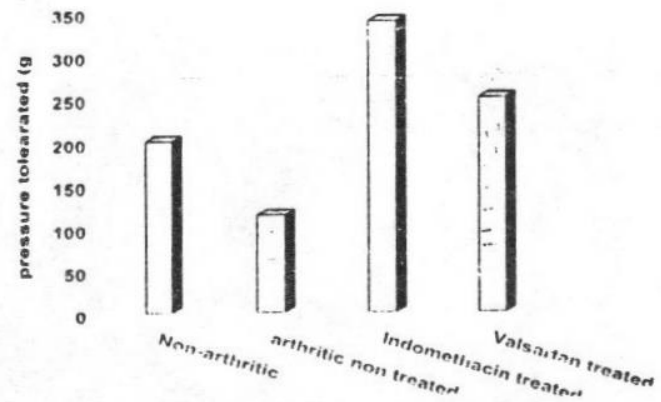

Fig (1) : Effect of either indomethacin or valsartan treatment on analgesmetry (gms).

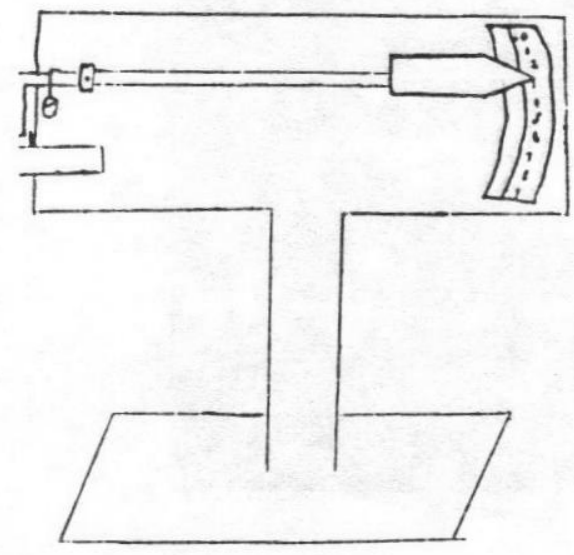

Fig (3) : Paw oedema meter.

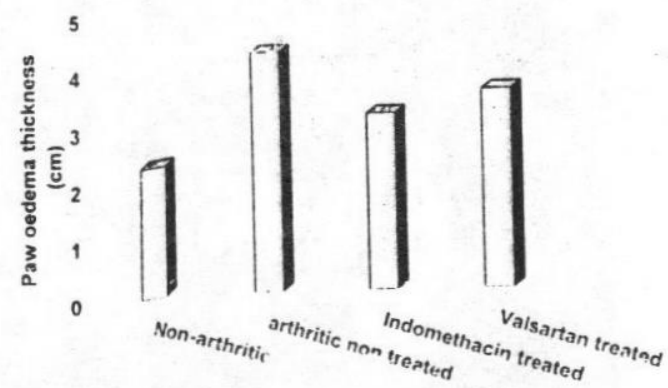

Fig (2) : Effect of either indomethacin or valsartan treatment on paw oedema thickness (cm).

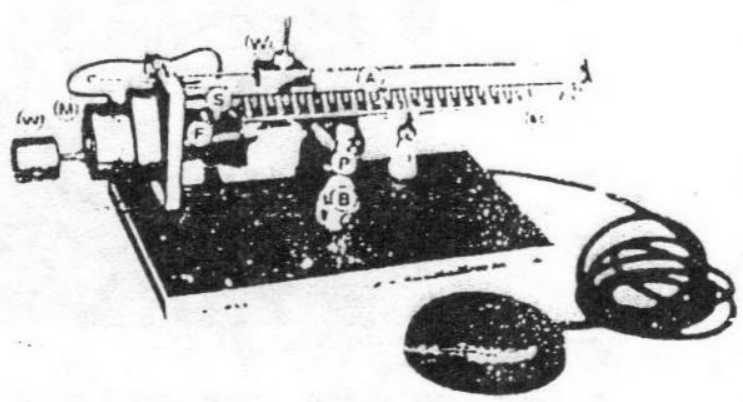

Fig (4) : Analgesymeter.

MANSOURA MEDICAL JOURNAL 


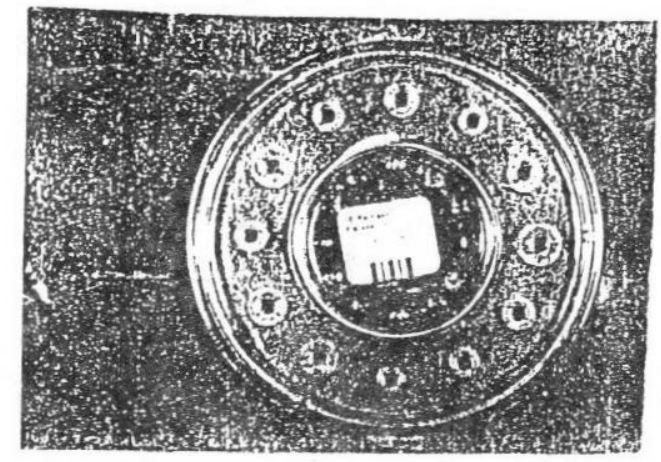

Fig (5) : Fibronectin immunodiffusion piate of the standard and arthritic control No 1,2,3= standard, from 4-12, arthritic control.

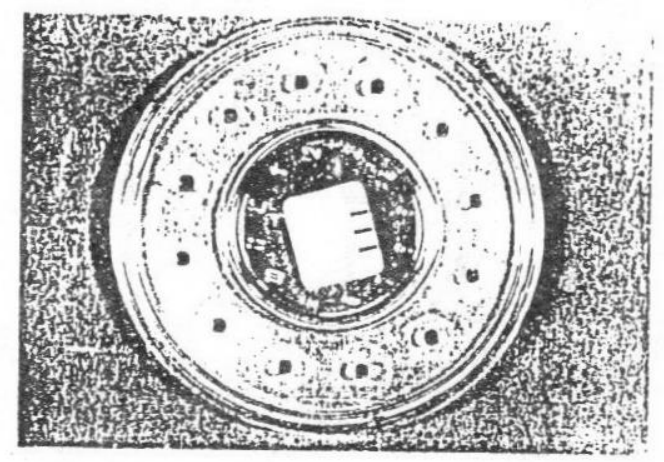

Fig (6) : Fibronectin immunodiffusion plate of arthritic rats treated with indomethacin.

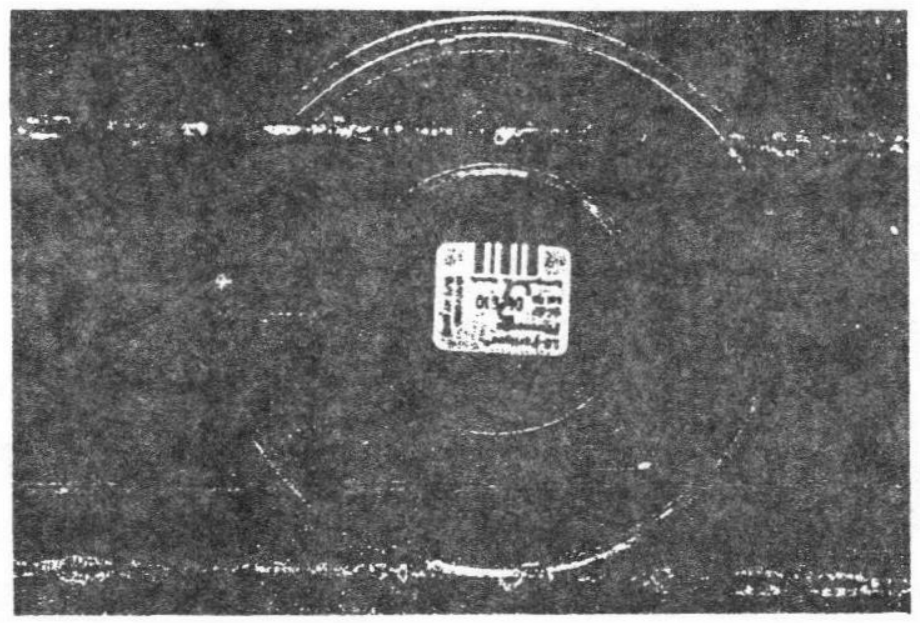

Fig. (7) : Fibroneetin immunodiffusion plate of arthritic rats treated with valsartan.

Vol. 36, No. 3 \& 4 July., \& Oct, 2005 


\section{DISCUSSION}

Inflammatory collagen polyarthritis developed in rats within 45 days after intradermal injection of type II collagen in complete freund's adjuvant (CFA) as evidenced by a significant decrease in pain threshold \& increase in mean hind paw oedema accompanied by increase in serum CRP, fibrinectin \& free oxygen radical. These results are in accord with that obtained by (21) as they reported that immunization with type II collagen in (CFA) induced polyarthritis \& immunity. The immunological mechanisms involved in the pathogenesis of type II collagen induced arthritis was initially suggested by dense polymorphnuclear (PMN) infiltration of synovium of arthritic joint (22\&23). Stoboda et al., (9) had been reported that type II collagen induced arthritis in rats considered as an experimental model of rheumatoid arthritis occurring in humans. In this model it was speculated that anti-type II collagen antibodies contributed to the incidence of arthritis (24).

Oral administration of indometha$\mathrm{cin}$ in a daily dose of $1.3 \mathrm{mg} / \mathrm{kg}$ for 2 weeks to rats with adjuvant-induced arthritis produced a significant antiinflammatory effect as indicated by improvement of paw oedema thickness, pain tolerance, serum CRP\& MDA but without a statistically significant changes in serum fibronectin $(F n)$ or serum creatinine. These findings are in accord with (25). These effects contribute to the analgesic- antiinflammatory actions of indomethacin.Furthermore it was reported that indomethacin didn't affect renal function (26) .

Administration of valsartan in a daily intragastric dose of $20 \mathrm{mg} / \mathrm{kg}$ for 2 weeks to rats with adjuvant arthritis produced significant improvement of paw oedema thickness, pain tolerance as well as a significant decrease in elevated serum CRP, MDA \& Fn, but without significant changes in serum creatinine as compared to arthritic non-treated rats table (1\&2). These findings could be explained on the light of previous studies which reported that Angll is responsible for production of $\mathrm{O}_{2}{ }^{*}$ \& $\mathrm{H}_{2} \mathrm{O}_{2}{ }^{* *}$ free radicals in cardiac, vascular smooth muscle, endothelial adventitial, and mesangial celis $(27,28,29)$. Furthermore, rantes (regulated upon activation, normal Tcells expressed and secreted) which is a member of C.C chemokine subfamily with chemoatractant properties for monocytes / macrophages

MANSOURA MEDICAL JOURNAL 
(M/M), eosinophils, granulocytes \& basophils to T-lymphocytes. Rantes induction is mediated by Ang II. Angiotensin converting enzyme inhibitors (ACEIS) \& Ang II-receptor antagonists may be effective in prevention of chemokine induction (30). In addition, it was found that AT1-receptor blockade with valsartan prevented the increase in TNF $\alpha$ in diabetic rats by acting on the Ang II at AT1 receptor levels. TNF $\alpha$ is $(M / M)$ derived cytokine that activates transcription factors such as nuclear factor kappa $B$ (NFKB) which induces expression of genes involved in inflammation \& cell growth (31). Fiebeler et al., \& Muller et al., $(32,33)$, had been found that valsartan suppressed the nuclear factor KB DNA binding activity \& reduced collagen $1 \& \mathrm{Fn}$ in the heart. In addition, it was reported that valsartan's beneficial effect in transgenic rats overexpressing the human renin and angiotensinogen genes (dTGR) are mediated by the inhibition of nuclear factor KB\& activator protein-1 (AP-1) (34). Furthermore valsartan protected the kidney from inflammation. This anti-inflammatory effect is not a result of lowering blood pressure, but is a result of direct action on cytokine TNF $\alpha$ at the level of the kidney. This finding made valsartan of a potential anti-inflammatory effect( ${ }^{(8)}$.

\section{Conclusions :}

From this study, it could be concluded that valsartan has comparable anti-inflammatory action as it attenuated the inflammatory response associated with collagen !I induced adjuvant arthritis. Clearly, further studies are necessary to declare if this potential anti-inflammatory effect of valsartan occurs in humans.

\section{REFERENCES}

1. Wolf, G. \& Wenzel, U.O. (2004) : Angiotensin II \& cell cycle regulation. Hypertension; 43:693. (Brief Reviews) .

2. Widdo P.R.E, Jones, E.S, Hannan $R$ \& caspari T (2003) : Angiotensin AT2 receptors: Cardiovascular hope or hype? British J pharmacol.; 140:809-824.

3. Trenthon, D.E. (1977) : Collagen arthritis as a relevant model for rheumatoid arthritis. Arthritis Rheü.; 25:911.

4. David, M; Clive, M.D. \& Jeffrey, S. (1984) : Renal syndromes associated with

Vol. 36, No. 3 \& 4 July., \& Oct, 2005 
non-steroidal antiinflammatory drugs. $\mathrm{N}$. Engl J Med; 310 (9): 563.
Effect of anti-inflammatory \& anti-rheumatic agents. Arthritis Rheum.; 24:616.
5. Somerville, K.; Faulkner, G \& Langman, M. (1986) : Nonsteroidal anti-inflammatory drugs in bleeding peptic ulcer. lancet; 1:462.

6. Michel Bunier, M.D. (2001) : Angiotensin II type -1 receptor blockers. Circulation; 103:904-912.

7. Thurman P.A. (2000) : Valsartan : a novel angiotensin type-1 receptor antagonist. Expert Opin Pharmacother; 1 (2) : 337-50.

8. Siragy, H.M; Awad, A; Abadir, P. \& Webb Randy (2003) : Angiotensin type 1 receptor mediates renal interstitial content of tumor necrosis factor- $\alpha$ in diabetic rats. Endocrinology; 44 (6): 2229 22333.

9. Stoboda A.E; Birnhaum J.E. \& Oransky, AL. (1981) : Studies on type II collageninduced polyarthritis in rats.
10. Noriko D, Richard Z. Lewanczuk, Anthony R, and Fakhreddin J (2004) : Rheumatoid Arthritis Does Not Reduce the Pharmacodynamic Response to Valsar$\tan$. The Journal of Clinical Pharmacology; 44 : 245252.

11. Chung NA, Lip GY, Beevers M\& Beevers DG (2001) : Angiotensin-II- receptor inhibitors in pregnancy. Lancet; 357 (9268) : 1620-1.

12.Eckhardt, S; Mitchell, N. \& Ceil, p.A. (1981) : Gollgen IIinduced arthritis in rats. $J$ Pharmacological Exp Therap; 220 (2) : 417.

13.RandalL, I.O. \& Selitto, J.J. (1957) : Analgesmeter. Arch Int Pharmacodyn.; $111: 409$.

14.Winter, C.A; Risely, E.A \& Nuss, G.W. (1992) : Paw oedemal test in experimentallyMANSOURA MEDICAL JOURNAL 
induced arthritis. Pros Soc Exp Biol Med;11:544.

16. Arthington J, Susan E, Kunkle, W\& Martin, $\mathbf{F ( 2 0 0 3 )}$ : Effect of Transportation and Commingling on the Acute Phase Protein Response and Growth and Feed Intake of Newly Weaned Beef Calves . Journal Of Animal Science; $1: 712$.

17. Draper, W. \& Hadley, M. (1990) : Methods enzymol; 186:421:431.

18. Yamada, K.M; Yamada S.S. \& Poston I. (1985) : The major cell surface glycoprotein of chick embryo fibroblasts is an agglutinin. Proc Natl Acad Sci (USA); 72:3158.

19. Seeling H.P. \& Wust, H. (1969) : Determination of serum creatinine. clinical Chemistry, 2nd edition, pp. 525.

20. Pipkins, F.B. (1984) : Statistical analysis of the obtained data descriptive \& comparative analysis in: "Medical statistical Made Ease"
Churchill Living stone publications. London,Mellbourne New York.

21 .Sasaki M, Kashima $M$, Ito $T$, Watanabe A, \& Izumiyama N (2000) : Differential regulation of metalloproteinase production, proliferation and chemotaxis of human lung fibroblasts by pdgf, interleukin-1 $\beta$ and TNF- $\alpha$. Mediators of inflammation; 9:3-4.

22. Trentham, D.E; Townes, A.S. \& Kany, A.H. (1977) : Autoimmunity to type II collagen; experimental model of arthritis. J Exp Med ; $44: 857$.

23.Trentham, D.E; Dynesius, R.A. \& Daird JR. (1978) : Passive transfer by cells of type II. Collagen Induced arthritis in rats. J Clin Invest; 11:539.

24. Cuzzocrea S, Wayman NS, Mazzon E, Dugo L\& Di Paola R (2002) : The Cyclopentenone Prostaglandin 15-Deoxy- delta 12,14-

Vol. 36, No. 3 \& 4 July., \& Oct, 2005 
Prostaglandin J2 Attenuates the Development of Acute and Chronic Inflammation. Molecular pharmacology. Vol. 61, Issue 5; 997 : 1007.

25. Schiozawa, S.; Yoshihara, R. \& Kuroki, Y. (1992) : Pathogenic importance of fibronectin in superficial region of articular cartilage as a local factor for the induction of pannus extension on rheumatic articular cartilage. Ann Rheum Dis ; 51(7) 869.

26. Komers R, Anderson S, Epstein M (2001) : Renal and cardiovascular effects of selec. tive cyclooxygenase-2 inhibitors. Am J Kidney Dis; 38 (6): 1145-57.

27. Ushio-Fukai M, Alexander, R.W; AkersM.; Yin Q, Fujio $Y$, Walsh K \& Griendly, KH. (1996) : Reactive oxygen species mediate the activation of AK/protective kinase $B$ by Angll in vascular smooth muscle. J Biol chem ; 274. 22699-22704.
28. Pagano, P.J.; Chanock, S.J; Siwik, D.A; Colucci, W.S. \& Clark, J.K. (1998) : Angiotensin II induces P67phox mRNA expression \& NADPH oxidase superoxide generation in rabbit aortic adventitial fibroblasts. Hypertension; 32:331-337.

29. Jaimes, E.A; Galceran, J.M. \& Raij, L. (1998) : Angiotensin !l induces superoxide anion production by mesangial cells kidney Int; 54:775784.

30. Wolf, G; Ziyadeh, FN; Thaisis, F; Tomas Jewsken, J; Caron, R.J; Wenzelu, Zahner, G., Helmchen, U. \& Stahl, RAK (1997): Angiotensin II stimulates expression of the chemokine Rantes in rat glomerular endothelial cells. Role of angiotension type-2 receptor. J clin Invest; 100:1047-1058.

31. Leongk, G. \& Karsan, A. (2000) : Signaling pathways mediated by tumor necrosis factora. Histol Histopathol; 15: 1303-1325.

MANSOURA MEDICAL JOURNAL 
32.Fiebeler, A; Schmidt, F; Muller, D.N; Park, J.K; Dechend $R$, Shagdarssuren $E$, Bieringer, M; Breu, V; Ganten, D; Luft F.C. \& Haller $H$ (2000) : Cardiac protective effect of aldosterone blockade is mediated through AP. 1 \& NF-KB suppression in angiotensin II -induced cardiac damage. Hypertension, 36:691.

33. Muller, D.N; Mervaala, E.M.A; Dechend, R; Fiebeler, A; Park, K.J; Schmidt, F; Thener, J; Breu, V; Mackman, N; Luther, T; Schneider w; Gulba, D; Ganten O, Haller, H. \& Luft, F.C.
(2000) : Angiotensin II (AT1) receptor blockade reduces vascular tissue factor in angiotensin II -induced cardiac vasculopathy. American Journal of pathology; 157:111-122.

34.Serneri, G.G.N; Boddi B; Modesti, P.A; Coppo, M; Cecioni, I; Toscanc M.T; Papa, M.B; Lisci, G.F. \& Chiavarelli, M. (2004) : Cardiac angiotensin II participates in coronary microvessel inflammation of unstable angina \& strengthens the immunomediated component. Circ Res; 94 (12): 16301637. 


\section{دراسة تأثير دواء الفالسرتان على إلتهاب المفاصل

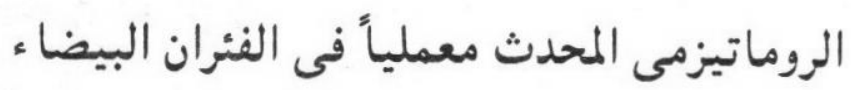

$$
\text { تسم الفارماكولوجيا الإكلينبكية - كلبة الطب مقبل اللطيف مقبل المنصورة - جمهورية مصر العربية }
$$

أجرى هذا البحث لدراسة إحتمال وجود تأثبر مضاد للإلتهاب لدواء الفالسرتان فى الفنران البيضاء المصابة بمرض الالتهاب المفصلى المحدث معسلياً.

استخدام لإجراء هذا البحث عدد بr بأراً أبيضاً وتسمت إلى أربعة مجموعات متساوية كل مجموعة تكونت من ^ ننران كالآتى:

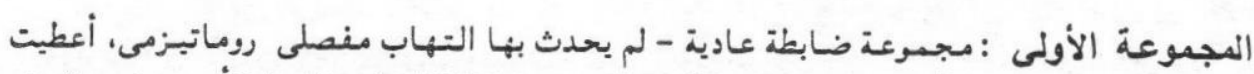
محلول ملح عادى بنفس الكمبة المستخدمة لإذابة الدواء ، وذلك لمدة أسبوعين متتاليين

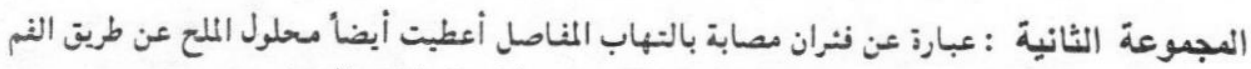

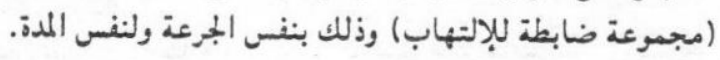

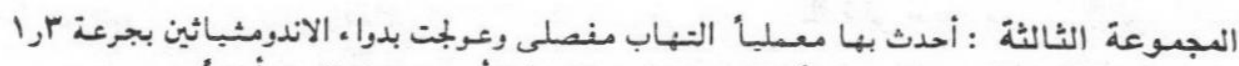
مجم/كجم يومباً وذلك عن طريق الفم لمدة أسبوعين متتاليبن بدرأ أيضاً.

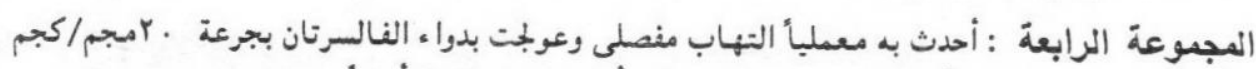
يومياً وذلك عن طريق الفم لمدة أسبوعين متتلبالبين أيضاً.

وتم تقييم الإلتهاب المفصلى المروماتيزمى بواسطة المعايير الآتية : - باس حجم الورم فى المخلب الملنفى للفنران بواسطة جهاز الاديمامتبر. - تباس مدى تحمل الألم بإحداث ضغط على المخلب الخلفى بواسطة جها; الأنلجينرمتير. - تباس مستوى البروتين - ج المتناعل فى المصل. MANSOURA MEDICAL JOURNAL 


$$
\text { - قباس معدل الشتوت الحرة فى المصل. }
$$

- احدث الالتبـاب انسصلى نقص ذو دلالة إحصائبة فى مدى تحسل الألم بإحداث ضغط على المخلب

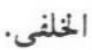

- أحدث الالتهاب المفصلى زيادة ذات دلالة إحصائبة فى حجم الورم نى المخلب الخلفى للفنران.

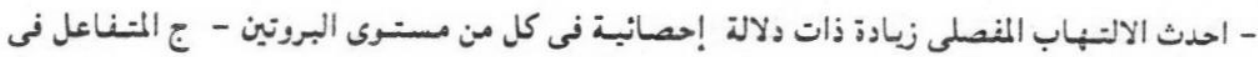

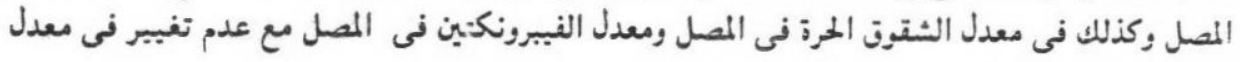

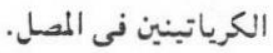

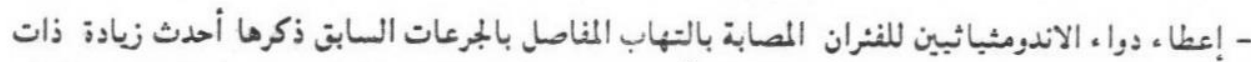

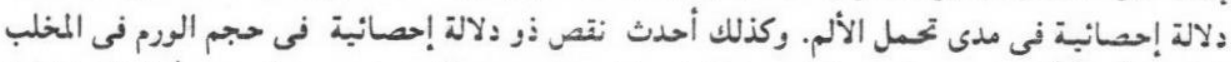

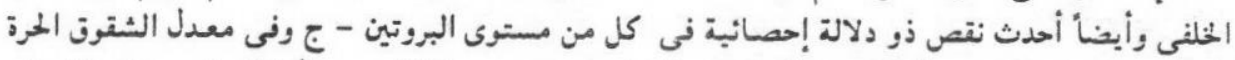

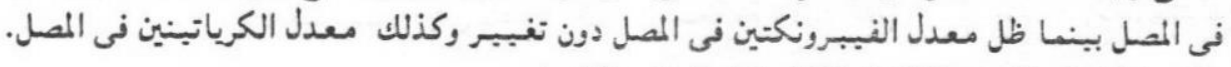
وذلك بالمقارنة بالمجموعة الضابطة المصابة بالتهاب المفاصل.

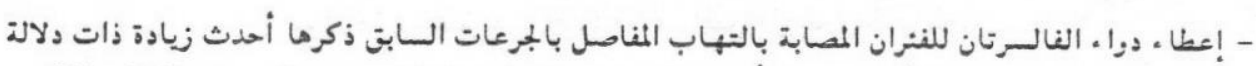

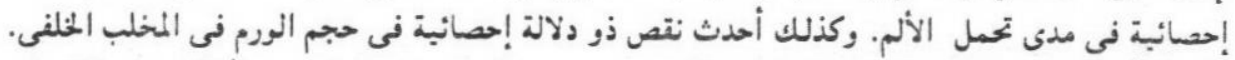

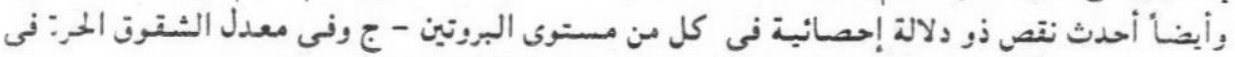

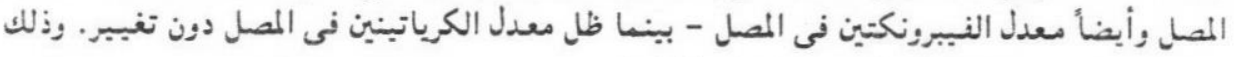
بالمقارنة بالمجموعة الضابطة المصابة بالتهاب المفاصل.

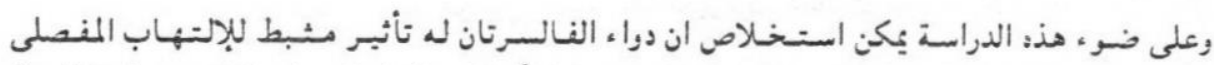

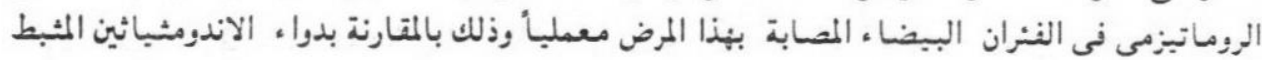

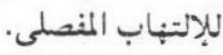

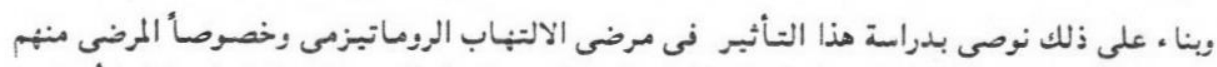

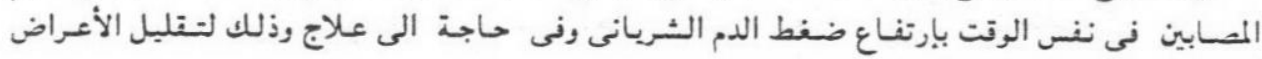
الجانبية وتقليل نفقات العلاج.

Vol. 36, No. 3 \& 4 July., \& Oct, 2005 